\title{
Globalization- A Gateway to Women Empowerment
}

\author{
Itishree Acharya \\ P. G. Department of English, U. N. College of Science and Technology (Autonomous), Adasapur, Cuttack, \\ Odisha
}

\begin{abstract}
Gender Equality or the disparity between women and men is unique to India. In India. In India discrimination against women starts in the foetus, followed by under nourishment in childhood and deprivation of education in adolescence and ends in domestic violence and bridge burning. These discrimination is a crime not merely against the women but also to women but it is a sin against humanity and civilization. They have been denied of education, mobility and means of production as well as denied of getting identification and recognize as individual voicing themselves. But in the era of Globalization it is proved that there is no basic difference in the mental capability of men and women. Women should have the same opportunities as men. Inequality based on the difference between males and females produces a dividing society with the sense of superiority on the side and a sense of inferiority on the other sides. Therefore sexual inequality has more divisive effect than any other form of inequality, it creates a feeling of hopelessness among the women since their sex is not the the product of their own action. In the era of modernization a workable solution could be put on economic, political and educational power within the reach of women with good guidance and support. It has been declared that on the occasion in fourth world conference on women held in 1995.
\end{abstract}

Keywords-Globalization, empowerment, family, marriage, dowry

\section{INTRODUCTION}

"Women rights are human rights". Empirical research shows that relative respect for women's wall being is strongly influenced by women's ability to earn an independent income, her ability to find employment at side home, her ability to have ownership rights and to have literature and be educated participants in decisions within and without the family. Education makes women more skilled and informed and property right allow her to be powerful participant in family decisions. Globalization has taken long strides to redeem women from male-dominated world by opening up opportunities for them. In the new world of globalization women were successfully attaining higher status and are enjoying greater economic freedom. New opportunities have come up to ameliorate the situation in which apartheid of gender has given way to new world of freedom for women.

"Gender Quake" in the $21^{\text {st }}$ century exposes the myth of women empowerment in the era of globalization. Globalization raises a voice against the discrimination and violence against women. Before Globalization women are being used as commodity to be sold in the market, through cosmetic sold in the market, industries, beauty contests, modelling new markets, most of them are also employed as maids and sex workers. It has been shown that sex industry of Japan earns billions of yens a year by importing women from their countries. Bangladesh and Srilanka and many other underdeveloped countries earn billions of dollars to pay off their loans caused by the economic reforms dedicated by the interests of the developed countries. The Concept of globalization turns to be a new challenge to the changes on the status of women, by creating new jobs for women and making constitutional provisions for their political rights. It has been observed that society is advancing very fast and the status of women is not improving along with the place of development. The position of empowerment varies from region to region, state to state and even between rural and urban areas and from one community to another. According to Swami Vivekananda "No society can progress men alone getting education and opportunities and women being neglected". It is education which gives us confidence, courage and inner strength. An educated women should inspire the society with her high thinking, decent behaviour and noble and integrated personality.

In 1898, Miss Margaret Elizabeth Nobel, who is popularly known as Sister Nivedita, though was a foreigner worked and died for the betterment of Indians. She used education as a tool to empower the Indian Society. She says" Education is a process through which women would learn to develop the power of thought, feeling will as well as moral of physical power to make their life more valuable and worth while to themselves and to the society'. Rabindranath Tagore affectionately called her 'Lokmata'. She had a grand role in the empowerment of women. She says lack of education means lack of self-reliance and self-confidence. For sister Nivedita, empowerment of women means the devolopmentof skills and abilities in women which keep them decide upon and to undertake actions which they believed were essential for their well being. A hundred years ago, Swami Vivekananda had said 'India's two national sins are the neglect of the masses and the neglect of the 
women'. It is only education through which women can solve their problems. Shri Ramakrishna's empowerment of his wife is unique. He never hurts his wife and worshipped her as 'Divine Goddess'. The result was that Sri Sarda Devi continued to live for thirty four years after the passing away from Sri Ramakrishna. Late Indira Gandhi once told that the happiest moment and deny in her life ' When she become a mother'! We must respect women as the embodiment of Divine mother.

In the era of Globalization media, both print and electronic plays a important role in bringing out the inherit qualities of women. It highlights their problems and motivates them to work. Now a days there is a degradation in the practice of evil customs like child marriage and purdah system by applying the compulsory registration of marriages. Now a days, more women are actively in the political parties and many legislatures measures have taken by government in the matter of inheritance of the property, employment, marriage, maternity benefits, crimes against women. Globalization has given more emphasis on man-women relationship. Today in the present situation the unity between man and woman is not merely physical but a unity of both mind and heart. It is law of love that binds them together. The Concept of Globalization has changed the mind of indian youths. They no more consider man- woman relationship as a relation existing between master or servant or exploiter or surpressor. There is a change in their mind-set or thinking process, through education, legal rights and social practice. Now a days women are no more dominated and they have made them free from the tyranny of man- made customs and laws. Gandhi exhorts women take bold, fearless and conscious of their place in the society, he clearly observes " The women who knows and fulfills her duty realizes her dignified status, she is the queen not the slave, of the household over which she presides. Gandhian Approach has a strong impact on the empowerment of women in the era of globalization. There are different women organization are working to reduce the crimes against the women by assisting police in the tracking down criminals. They can be harbingers of communal harmony. Their voice always stand for peace and harmony in international relations.

In the $21^{\text {st }}$ century, women are achieving their lost identity and enjoying autonomous and independent status. She is no more an 'object' or 'other sex' rather a conscious human being. Governmental organizations translate women's empowerment into policies and programs and are creating new models for the future. There are number for improving the social status of women. The UNO has launched programmes for the education and health care of women throughout the world. The empowerment of women and the weaker sections of the society is one of the priority areas of the $9^{\text {th }}$ five year plan (1997-2002). The national Education system will pay a positive interventionist role in the empowerment of women. In the rural areas women are engaged in farming, handloom, handicraft and other small industries and instructions etc besides looking after the family by rearing children, cooking, cleaning, washing and other domestic chores, although the condition of the working women in the urban societies are comparatively better than them. Sarada Devi works as a model for the empowerment of women. She become the guiding force of the 'Ramakrishna mission' which stands for the spiritual education and worldly welfare of the society. Globalization brings education, economic independence, property rights which creates self-confidence in women and it would concentrate the dreams of empowerment. The men and women would live in co-partnership which is very important for the upliftment and empowerment of women. Now Government has taken steps regarding the evil of female- foeticide The Indian constitution guarantees equality between the men and women and a number of laws has been enacted from time to time to implement these guarantees on the matter of inheritance of property, their employment, marriage, maternity benefits and crimes against the women. It illustrates women are ignorant of their rights, the law itself becomes handicappedpersonal laws, uniform civil codes, Human rights commission, MahilaAyog will become force. Globalization attempts to educate illiterate mass through radio, television, news and magazines to end the discrimination against the women. Globalization stands as a gateway to woman empowerment.

\section{REFERENCES}

[1] James Petras, Globalization:A social Perspective, Economic and political Weekly, Feb 20, 1999.

[2] Sumit Roy, Globalization, Structural Change and Poverty Economic and political weekly, August 16-23 1997 Pg-23

[3] Sen, Amartya, The Food Problem: Theory and practice in A.Gauhar(ed), South-south stratergy, (London: Third world foundation, 1983)

[4] Singh, Sachinanda Kumar, Women Empowerment in India, (London: Oxford Publication, 2010)

[5] Sen, Amartya, Individual Freedom, The Times of India, Patna, $16^{\text {th }}$ October, 98 